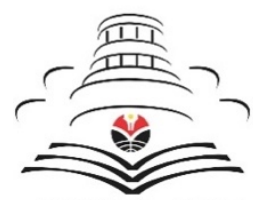

JURNAL UPI

\title{
JAPANEDU:
}

Jurnal Pendidikan dan Pengajaran Bahasa Jepang

http://ejournal.upi.edu/index.php/japanedu/index

\section{The Perceptual Ability to Identify Japanese Language Accent Patterns by Indonesian Learners}

\author{
Franky Reymond Najoan \\ Universitas Negeri Manado, Manado, Indonesia \\ franky.najoan@yahoo.com
}

\begin{abstract}
A B S T R A C T
Research on the acquisition of suprasegmental sounds in Japanese has been carried out both in terms of production and perception. The conducted research shows that there are difficulties in acquiring Japanese sounds. This study focused on the perception of Japanese accents, with the aim of describing the learner's ability to identify Japanese accent patterns. The data sources of this research are Japanese learners at beginner level. Data were collected using a test instrument, through a hearing test, in the form of a set of words which selected based on the category of words and patterns of Japanese accents to be measured by listening and recording techniques. The results showed that based on the results of the hearing test, of the 17 participants who completed the test reached the highest score 47.14 (S01), and the lowest score of 15.41 (S14), with an overall average score of 29.16 and Standard Deviation (SD) 7.9018. These scores represent the participants' ability to identify Japanese accent patterns is in the very low category. The results indicate that the learners have difficulty identifying Japanese accent patterns. In fact, the vocabulary in research instrument was the basic vocabulary that had been learned by them. It can be concluded that the acquisition of vocabulary is not in line with the suprasegmental elements attached to these words. The results of this research need to be continued by applying listening exercises of Japanese accent.
\end{abstract}

Accent; Language acquisition; Perception; Suprasegmental

\section{K E Y W O R D S}

First received: 13 May 202

A R T I C L E I N F O

Available online: 19 December 2021

\section{PENDAHULUAN}

Tahap pertama proses penguasaan bahasa adalah melalui proses pendengaran. Dalam bidang psikolinguistik, proses pendengaran ini disebut persepsi. Persepsi merupakan suatu proses pengindraan, stimulus yang diterima oleh individu melalui alat indera yang kemudian diinterpretasikan sehingga individu dapat memahami dan mengerti tentang stimulus yang diterimanya tersebut. Proses menginterpretasikan stimulus ini biasanya dipengaruhi pula oleh pengalaman dan proses belajar individu (Dardjowidjojo, 2005). Teori "kontras dan proses" yang dikembangkan oleh Ingram (1975) menyimpulkan bahwa dalam pemerolehan fonologi persepsi mendahului produksi (Kuntarto, 2017). Di sisi lain, proses penguasaan bahasa pada 
umumnya melalui pendengaran yang melibatkan persepsi. Persepsi adalah peristiwa ketika telinga menangkap sebuah bunyi yang dapat berupa bunyi lepas, kata, atau kalimat (Su'udi, 2011), yang sering menjadi fokus pengamatan dalam proses pemerolehan dan pembelajaran bahasa. Meskipun demikian, pembelajaran bahasa asing tidak hanya mengutamakan unsur produksi bahasa, tetapi juga mengutamakan unsur persepsi. Dan ketika memberikan pelatihan lafal, produksi, dan persepsi harus dilakukan bersama-sama.

Manusia mengenal bahasa mulai dari pendengaran. Kemampuan berbicara seorang anak terbentuk setelah melalui proses pendengaran dalam suatu kurun waktu tertentu, yang merupakan input bahasa. Seseorang dapat sedikit demi sedikit mengeluarkan output berupa ujaran berdasarkan input yang telah diterimanya dalam jangka waktu tertentu. Menurut Chomsky, hal ini terjadi karena manusia sejak lahir telah dibekali suatu kemampuan berbahasa dalam bentuk sebuah alat yang disebut LAD (Language Acquisition Device) (dalam Barman, 2012). Berdasarkan alat inilah input diproses kemudian dikeluarkan dalam bentuk output yaitu ujaran. Tidak ada seorang pun yang mengajarkan seorang anak bagaimana cara mengucapkan suatu bunyi bahasa selain anak itu sendiri yang mencoba mengucapkan berdasarkan input yang ia dapatkan. Hal ini merupakan bukti bahwa LAD bekerja untuk suatu kemampuan bahasa seseorang (Brown, 1980).

Untuk menguasai sebuah bahasa asing, pembelajar harus mengetahui persepsi (pendengaran) dan produksi ujaran (pelafalan), karena kemahiran bahasa adalah perpaduan antara persepsi dan produksi. Penelitian mengenai pemerolehan bunyi bahasa Jepang telah banyak dilakukan baik dari segi produksi maupun persepsi antara lain oleh Toda (1998, 2003), Oguma (2000), Hatasa, Takahasi, dan Ito (2016), Wang, Hayashi, Isomura, dan Arai (2017), dan Suenobu (2020). Oguma (2000) meneliti persepsi chouon dan tan'on oleh pembelajar yang berbahasa ibu bahasa Inggris, mendapati bahwa chouon yang terletak di posisi akhir kata merupakan yang paling sulit pemerolehannya.

Penelitian mengenai lafal bahasa Jepang, juga sudah cukup banyak dilakukan. Sukegawa (1993) meneliti lafal aksen pembelajar Indonesia dan menemukan sejumlah eror dalam lafal aksen. Hal ini dikarenakan adanya masalah dalam proses persepsi sehingga pembelajar tidak dapat sepenuhnya menguasai pola-pola aksen bahasa Jepang.
Sukegawa (1999) juga meneliti tentang realisasi pitch aksen bahasa Jepang oleh pembelajar asal Brazil, dan mendapati bahwa pembelajar menerapkan pola interlanguage dalam lafal dan cenderung menerapkan nada tinggi pada havy syllabel. Sedangkan Ayusawa (2003) melakukan review terhadap penelitian tentang pemerolehan aksen dan intonasi bahasa Jepang sejak 1990, dan menemukan bahwa penelitian terhadap persepsi dan produksi mengalami kemajuan dengan adanya kemajuan teknologi komputer. Toda (2003) mengkaji tentang pemerolehan special morae, dan Najoan, Yokoyama, Usami, Isomura dan Kubota (2012) meneliti tentang pemerolehan chouon terhadap pembelajar Indonesia mendapati adanya kesulitan pembelajar dalam pemerolehan bunyi chouon.

Persepsi dalam berbahasa merupakan suatu proses mendengar, menyimak, diinterpretasikan dan dimengerti. Indah (2017) menyatakan bahwa persepsi merupakan proses individu mengumpulkan, menafsirkan dan memahami informasi melalui piranti akal. Riset mengenai persepsi mencoba untuk memahami bagaimana manusia mendengar dan memahami suara yang berisi kata-kata dan menggunakan informasi yang diperoleh untuk memahami bahasa yang diucapkan. Proses pemahaman bahasa ini dimulai dari tingkat suara di mana sinyal audio akan diproses seperti dalam pendengaran.

Penelitian mengenai aksen selama ini berdiri pada anggapan dasar atau hipotesis bahwa unsurunsur bahasa yang sama antara B1 dan B2 membantu proses pemerolehan (Lado, 1957). Penelitian yang dilakukan oleh Minagawa terhadap pembelajar yang berbahasa ibu bahasa Korea, Thailand, China, Inggris, dan Jerman untuk mengukur bagaimana mereka mengidentifikasi pola aksen dalam silabel bunyi panjang, menunjukkan bahwa hanya pembelajar yang berbahasa ibu bahasa Thailand yang dapat mengidentifikasi pola aksen dengan baik karena ada kesamaan sistem bunyi antara bahasa Thai dengan bahasa Jepang (Minagawa, 1997). Hasil penelitian tersebut menunjukkan bahwa memang unsur-unsur yang memiliki kesamaan dapat membantu proses pemerolehan. Namun demikian tidak semudah itu, karena setiap kata memiliki aksennya sendiri, sehingga perlu untuk diketahui lagi faktor-faktor lain agar lebih mempermudah proses pemerolehan.

Sebagai sebuah sistem, bahasa Jepang juga bersifat sistematis dan sistemis. Secara sistematis berarti bahasa Jepang tersusun menurut suatu 
pola, sedangkan sistemis berarti bahasa Jepang bukan merupakan suatu sistem tunggal, tetapi terdiri dari sub-sub sistem yang merupakan satu kesatuan bahasa Jepang. Begitu juga aksen Bahasa Jepang ternyata tersusun secara sistematis, setiap jenis kata kerja memiliki sistem pola aksennya. Misalnya kata kerja memiliki aksen berdasarkan golongan, dan setiap golongan verba memiliki sistem perubahan secara morfologis. Ternyata perubahan bentuk kata juga diikuti dengan perubahan pola aksen, namun perubahan itu secara teratur sehingga memudahkan pembelajar untuk memahami dan menguasai aksen kata kerja/verba (Najoan, 2018). Sistem aksen seperti ini dapat membantu pembelajar menguasai aksen bahasa Jepang (Najoan, 2019). Tetapi timbul pertanyaan apakah secara persepsual pembelajar dapat mengidentifikasi pola-pola aksen tersebut?

Berbagai penelitian membuktikan bahwa salah satu kesulitan dalam belajar dan pembelajaran bahasa Jepang adalah masalah lafal, khususnya untuk masalah durasi bunyi segmental dan suprasegmental (baik dari segi persepsi maupun produksi) dan tekanan. Bunyi suprasegmental merupakan unsur yang sangat penting dalam bahasa Jepang karena mempunyai fungsi pembeda makna (distinctive feature). Untuk memecahkan masalah ini perlu terus dilakukan penelitian dari berbagai sudut pandang.

Penelitian kali ini difokuskan pada masalah tekanan dalam kata yang dikenal dengan istilah aksen. Masalah aksen menjadi sangat penting dalam bahasa Jepang karena fungsinya dapat membedakan makna kata sehingga sangat penting dalam komunikasi, dan memerlukan perhatian ekstra dari pembelajar untuk menguasainya. Masalah lafal dilihat dari dua segi, yaitu segi produksi dan persepsi. Penelitian ini khususnya mengangkat kemampuan pembelajar dalam mengidentifikasi pola aksen bahasa Jepang, terutama saat awal mempelajari bahasa Jepang. Meskipun telah terbukti bahwa pola aksen bahasa Jepang tersusun secara sistematis, namun belum diukur bagaimana kemampuan mendengar (persepsi) para pembelajar. Untuk itu penelitian kali ini bertujuan hendak melakukan pendalaman mengenai kemampuan pembelajar mengenali pola-pola aksen bahasa Jepang secara persepsual. Apabila pembelajar mampu mengenali pola-pola aksen bahasa Jepang akan mempermudah pelafalan yang benar.

Hasil penelitian ini diharapkan dapat memberi kontribusi dan masukan untuk melengkapi bahanbahan dalam rangka penyusunan bahan ajar atau materi pembelajaran lafal bahasa Jepang. Dengan demikian maka bahan ajar ini dapat memberikan alternatif bagi praktisi pendidikan bahasa Jepang untuk menyusun silabus pembelajaran lafal bahasa Jepang kepada pembelajar Indonesia. Bagi pembelajar bahasa Jepang, hasil penelitian ini akan memberikan kemudahan belajar, sedangkan bagi pengajar bahasa Jepang, sangat berguna untuk menyusun strategi pembelajaran yang efektif dan efisien.

\section{TINJAUAN PUSTAKA}

\section{Persepsi Bahasa}

Persepsi adalah tanggapan (penerimaan) langsung dari sesuatu; serapan, proses seseorang mengetahui beberapa hal melalui pancaindranya (KBBI). Menurut kamus lengkap psikologi, persepsi adalah: a) proses mengetahui atau mengenali objek dan kejadian objektif dengan bantuan indra, b) kesadaran dari proses-proses organis, c) Satu kelompok pengindraan dengan penambahan arti-arti berasal dari pengalaman di masa lalu, c) variabel yang menghalangi atau ikut campur tangan, berasal dari kemampuan organisasi untuk melakukan pembedaan di antara perangsang-perangsang, d) kesadaran intuitif mengenai kebenaran langsung atau keyakinan yang serta merta mengenai sesuatu (Chaplin, 2005). Dalam psikologi bahasa, persepsi berhubungan dengan proses pendengaran. Kemampuan persepsi bahasa adalah kemampuan menangkap sinyal bukan hanya sekedar bunyi tetapi bunyi-bunyi yang membentuk suatu stimulus. Persepsi dalam penelitian ini adalah interpretasi dari otak terhadap rangsangan bunyi bahasa dalam hal ini pola-pola aksen bahasa Jepang. Menurut Ingram (1975), persepsi dalam konteks pemerolehan bahasa kedua mendahului produksi (Kuntarto, 2017).

Dalam teori pemerolehan bahasa kedua menurut Haynes (2007) dan Ellis (1994), dijelaskan bahwa berdasarkan proses perkembangannya, pemerolehan bahasa kedua dapat dibagi menjadi lima tahap, yaitu: praproduksi, produksi awal, bicara awal, fasih, dan mahir. Pra-produksi adalah tahap awal yang dikenal juga dengan periode senyap, dimana pembelajar tidak banyak berbicara karena mereka hanya menguasai kosakata reseptif hingga $500 \mathrm{kata}$ (Haynes, 2007). Namun, tidak semua pembelajar melalui tahap periode senyap. Beberapa pelajar bisa saja langsung memasuki tahap berbicara, 
meskipun kata-kata yang mereka gunakan hanya meniru, bukan kreativitas sendiri. Bagi para pembelajar yang melewati periode senyap, biasanya hal itu hanya berjalan selama tiga sampai enam bulan (Ellis, 1994). Tahap kedua dari pemerolehan bahasa kedua (B2) adalah produksi awal, pada tahap ini pembelajar dapat mengucapkan frasa-frasa pendek antara satu atau dua kata. Mereka juga dapat mengingat potonganpotongan kata dalam bahasa kedua, meskipun masih mengalami banyak kesulitan dan kesalahan saat menggunakannya. Menurut Ellis pembelajar B2 pada tahap ini telah memiliki baik kosakata aktif dan pasif sekitar 1000 kata (Ellis, 1994). Selanjutnya, tahap ketiga adalah awal bicara. Kosakata pembelajar bahasa kedua pada tahap ini meningkat hingga 3000 kata, dan mereka mampu berkomunikasi menggunakan kalimat tanya sederhana. Mereka juga masih mengalami kekeliruan gramatikal (Haynes, 2007). Setelah awal bicara adalah tahap fasih menengah, yaitu tahap pembelajar telah memiliki lebih dari 6000 kosakata, dan dapat menggunakan kalimat dengan struktur yang lebih kompleks (Ellis, 1994). Pada tahap ini juga mereka mampu berbagi pikiran dan pendapat. Namun, tetap saja pembelajar masih menemukan kesalahan selama membentuk kalimat-kalimat kompleks. Tahap terakhir adalah mahir, yang biasanya tercapai antara lima sampai sepuluh tahun belajar B2 (Ellis, 1994). Pada tahap ini kemampuan pelajar semakin dekat dengan penutur asli (Haynes, 2007).

\section{Penelitian Terdahulu tentang Persepsi Bahasa}

Penelitian sebelumnya tentang persepsi bahasa Jepang dilakukan oleh Sukegawa dan Sato (1994) mengenai persepsi aksen bahasa Jepang oleh pembelajar Korea, yang hasilnya menunjukkan bahwa pembelajar Korea mengalami kesulitan mengidentifikasi pola-pola aksen bahasa Jepang, dan menerapkan pola bahasa Ibu (Sukegawa, 1994). Selain itu, Maekawa dan Sukegawa (1995) yang juga meneliti aksen pembelajar asal Korea, menemukan bahwa perubahan pitch dalam silabel chouon memberikan pengaruh positif terhadap persepsi bunyi panjang. Toda (1998) meneliti tentang persepsi chouon, sokuon, dan hatsuon oleh penutur bahasa Inggris, dan menyimpulkan bahwa pembelajar mengalami kesulitan dalam mengidentifikasi bunyi-bunyi tersebut. Selanjutnya, Minagawa, Maekawa, dan Kiritani (2002) meneliti tentang persepsi penutur bahasa Inggris dan bahasa Korea tentang pengaruh aksen dalam mengidentifikasi bunyi chouon, menyimpulkan bahwa pitch dapat mempengaruhi pendengar untuk mengidentifikasi panjang pendeknya vokal. Meskipun banyak ditemukan penelitian yang mengangkat kemampuan pelafalan bahasa Jepang oleh pembelajar dari berbagai negara, belum banyak ditemukan penelitian yang mengangkat objek pembelajar penutur asli Indonesia dan kemampuan mereka dalam mengenal pola-pola aksen bahasa Jepang.

\section{Sistem dan Pola Aksen Bahasa Jepang}

Ada berbagai definisi mengenai aksen menurut para ahli, namun berdasarkan kamus bahasa Indonesia dapat diketahui bahwa pengertian aksen ada 4 antara lain aksen sebagai unsur linguistik; aksen sebagai ciri kebahasaan seseorang yaitu alunan nada yang dimiliki oleh masing-masing orang sesuai asal daerah mereka sendiri; aksen yang menunjuk pada istilah dalam seni; dan aksen sebagai tanda diakritik. Dari keempat pengertian aksen di atas, yang berhubungan dengan bahasa adalah pengertian yang pertama, yang berarti tekanan suara pada kata atau suku kata. Sehingga yang dimaksud dengan aksen dalam penelitian ini adalah tekanan suara dalam kata.

Setiap bahasa memiliki aksen masing-masing, namun yang membedakan adalah apakah aksen itu berfungsi membedakan arti atau tidak. Aksen bahasa Indonesia tidak membedakan makna sehingga disebut tidak fungsional, dan tekanan suara pada umumnya terletak pada suku ke dua dari belakang kata. Misalnya kata "makan" /makan/ aksennya terletak pada suku kata /ma-/; kata "pekerjaan" /pe-ker-ja-an/ aksennya terletak pada suku kata /-ja-/. Namun demikian, posisi aksen ini tidak mutlak dalam bahasa Indonesia. Misalnya, sekalipun kata "makan" diucapkan dengan aksen pada suku kata /-kan/, tidak akan mengubah makna kata tersebut, sehingga aksen dalam bahasa Indonesia tidak fungsional, karena tidak mempunyai fungsi sebagai pembeda makna (Halim, 1984).

Sedangkan dalam Bahasa Jepang, perbedaan pola aksen akan menyebabkan perbedaan makna kata, sehingga aksen sangat penting dalam komunikasi lisan. Aksen bahasa Jepang disebut aksen nada (pitch accent). Misalnya, kata "ame" mempunyai dua jenis aksen, yang pertama tekanan suaranya atau tinggi nada terletak pada suku atau mora pertama, sedangkan yang kedua tinggi nadanya terletak pada semua suku/mora sehingga disebut aksen datar. Jika diucapkan 
dengan nada tinggi pada suku pertama maka makna kata áme adalah 'hujan', sedangkan jika diucapkan dengan aksen datar makna kata menjadi 'permen'. Dengan demikian aksen bahasa Jepang harus mendapat perhatian dalam proses pemerolehan dan pembelajaran.

Sebagai sebuah unsur kebahasaan yang memiliki sistem, aksen bahasa Jepang tersusun secara teratur dan memiliki pola dan distribusi aksen berdasarkan jenis kata. Bahasa Jepang memiliki 4 pola aksen. Pola-pola dimaksud adalah (1) aksen awal, yaitu tinggi nada terletak pada suku/mora pertama atau pada awal kata yang disebut atamadakagata (頭高型), (2) aksen tengah, yaitu tinggi nada terletak pada suku/mora yang berada di tengah kata, yang disebut nakadakagata (中高型), (3) aksen akhir, yaitu tinggi nada berada pada semua suku/mora tatapi nada turun sesudah suku terakhir, dalam bahasa Jepang disebut odakagata (尾高型), (4) aksen datar, yaitu semua suku/mora mendapat tekanan atau tinggi nada yang sama dan tidak pernah turun, dalam bahasa Jepang disebut heiban gata (平板型) (Koizumi, 1993; The Japan Foundation, 2009).

Keempat pola aksen tersebut di atas tersebar pada semua kosakata bahasa Jepang. Namun untuk memudahkan pemahaman, pola tersebut umumnya dibagi ke dalam kelompok atau kategori tertentu. Misalnya, seperti di jelaskan di dalam kamus OJAD, semua kata tanya (dore, doko, dochira, nani, dsb) memiliki pola aksen awal, atamadakagata (頭高型), dan sebaliknya kata-kata penunjuk seperti kore, sore, are, koko, soko, asoko, kochira, sochira, dochira, dan sebagainya termasuk pola aksen datar (heiban gata/平板型) (Minematsu Laboratory, 2021). Kategorisasi dapat juga dilakukan menurut jenis kata, seperti, kata benda, kata sifat, kata kerja, dan sebagainya (Minematsu Laboratory, 2021). Sekalipun proses perubahan bentuk kata secara morfologis cukup banyak, namun pola aksennya tersusun secara teratur dan dapat dimanfaatkan untuk proses pembelajaran aksen bahasa Jepang.

Penelitian tentang aksen dari sudut pandang persepsi diantaranya telah dilakukan oleh Esop sejak 1994 sampai 1999 terhadap pembelajar asing, menggunakan tes persepsi yang dikembangkan oleh Nishinuma (1994), Takashi dan Cutler (1999), dan Nishinuma, Ayusawa, dan Abe (1996). Ayusawa (2003) dalam rangkaian penelitiannya menyimpulkan bahwa respons para pembelajar terdapat perbedaan secara individual yang cukup besar dan tidak ada hubungan dengan riwayat belajar para pembelajar. Hasil penelitian menunjukkan bahwa jawaban benar paling banyak terdapat pada aksen pola datar, dan pola aksen yang mirip dengan pola aksen bahasa ibu pembelajar lebih mudah diidentifikasi, dimana hal ini disebut sebagai "perceptual transfer" (Broselow, Hurtig, \& Ringen, 1987). Byun (2018) menganalisis persepsi native speaker terhadap aksen standar bahasa Jepang (aksen Tokyo) berdasarkan daerah asal, dan mendapati bahwa penutur asli (native speaker) pun mengalami kesulitan dalam mengidentifikasi pola-pola aksen bahasa Jepang.

\section{METODE DAN TEKNIK PENELITIAN}

Penelitian ini menggunakan metode deskriptifkualitatif. Data-data diperoleh dari sumber data melalui tes persepsi dan dideskripsikan secara kualitatif untuk mendapatkan suatu gambaran keadaan masa kini atau gambaran terkini mengenai kemampuan pembelajar mengenal atau mengidentifikasi bunyi bahasa Jepang secara persepsi.

Prosedur penelitian dilaksanakan dengan memberikan penjelasan mengenai sistem aksen bahasa Jepang dan pelafalan yang benar dengan menggunakan tanda-tanda aksen yang berlaku di Jepang maupun secara internasional kepada pembelajar. Kemudian pembelajar diminta untuk menyimak sebuah teks dan mengidentifikasi bunyi-bunyi yang menjadi target penelitian yang dikemas dalam bentuk instrumen penelitian, serta menuangkannya dalam bentuk tanda-tanda aksen.

Instrumen penelitian (dapat dilihat pada lampiran) terdiri dari 70 kosakata dasar yang diambil dari buku ajar Minna no Nihongo (3A Network, 1999) yang diklasifikasikan menurut pola aksen. Kata-kata tersebut merupakan kosa kata yang sudah dipelajari oleh pembelajar yang menjadi subjek penelitian ini.

\section{Pengumpulan Data}

Sumber data penelitian ini adalah 17 orang pembelajar bahasa Jepang tingkat pemula yang sedang belajar bahasa Jepang di program studi pendidikan bahasa Jepang, dan merupakan mahasiswa semester 3 pada saat pengambilan data.

Teknik pengumpulan data menggunakan teknik simak dengan alat bantu audio, dimana pembelajar diberikan tes pendengaran. Data 
dikumpulkan menggunakan instrumen tes, yang berisi seperangkat kata yang dipilih berdasarkan kategori kata dan pola aksen bahasa Jepang yang hendak diukur dalam penelitian ini.

\section{Teknik Pengolahan Data}

Data yang terkumpul mula-mula dikategorikan menurut jenis atau kelompok subjek dan materi. Tes dalam penelitian ini terdiri dari 70 kata (lihat lampiran), dan hasil tes direkapitulasikan berdasarkan kelompok peserta tes dan berdasarkan kategori kata. Hasil perolehan nilai tes dihitung menggunakan rumus persentase, kemudian dikategorikan menurut kemampuan: A (>85), B $(75-84), \mathrm{C}(51-74)$ dan $\mathrm{D}(\leq 50)$.

\section{HASIL DAN PEMBAHASAN}

\section{Hasil Tes Pendengaran}

Penelitian dilaksanakan terhadap pembelajar yang belajar bahasa Jepang tingkat dasar berjumlah 17 orang. Hasil tes pendengaran adalah sebagai berikut

Tabel 1: Daftar perolehan nilai Tes Pendengaran.

\begin{tabular}{cc}
\hline Subjek & Nilai \\
\hline S01 & 47,14 \\
S03 & 41,43 \\
S05 & 38,57 \\
S17 & 35,71 \\
S04 & 32,86 \\
S07 & 32,86 \\
S10 & 28,57 \\
S15 & 28,57 \\
S16 & 28,57 \\
S08 & 27,14 \\
S09 & 25,71 \\
S06 & 24,29 \\
S12 & 24,29 \\
S13 & 22,86 \\
S02 & 21,43 \\
S11 & 20,00 \\
S14 & 15,71 \\
\hline Mean & 29,16 \\
\hline SD & 7,9018 \\
\hline
\end{tabular}

Berdasarkan hasil tes pendengaran seperti tampak pada Tabel 1 dan Gambar 1, dari 17 peserta yang menyelesaikan tes tersebut, perolehan nilai tertinggi adalah 47,14 (S01), dan nilai terendah adalah 15,41 (S14), dengan nilai rata-rata dari keseluruhan adalah 29,16 dengan Standar Deviasi (SD) 7,9018. Perolehan nilai ini menunjukkan kemampuan peserta mengidentifikasi pola aksen bahasa Jepang berada pada kategori D dapat dikategorikan sangat rendah. Hal ini menunjukkan bahwa pembelajar mengalami kesulitan mengidentifikasi pola-pola aksen bahasa Jepang.

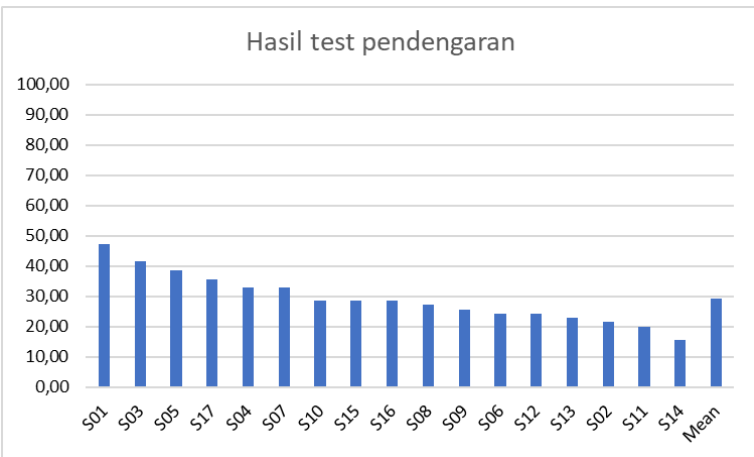

Gambar 1: Hasil Tes Pendengaran.

Ada banyak alasan yang dapat dipertimbangkan sebagai penyebab rendahnya kemampuan persepsi para pembelajar. Pertama dari segi linguistik, pola aksen bahasa Jepang dan bahasa Indonesia berbeda baik secara fonetis maupun secara fonologis. Secara fonetis, aksen bahasa Jepang memiliki pola yang tetap dan bersifat fungsional sebagai pembeda makna (distinctive feature). Sedangkan aksen bahasa Jepang memiliki 4 pola, yaitu pola aksen awal (atamadakagata), pola aksen tengah (nakadakagata), pola aksen akhir (odakagata), dan pola aksen datar (heibangata) (Japan Foundation, 2009). Dibandingkan dengan aksen bahasa Indonesia yang berpola sederhana, pola aksen bahasa Jepang lebih rumit dan bersifat tetap.

Secara fonologis, aksen bahasa Jepang bersifat distingtif, sedangkan aksen bahasa Indonesia tidak membedakan makna. Bahasa Indonesia memiliki pola tetap, yaitu tekanan kata terletak pada suku kedua dari belakang kata, namun tidak fungsional sehingga tidak menjadi perhatian bagi penutur bahasa Indonesia (Halim, 1984). Perbedaan ini menjadi salah satu kendala bagi pembelajar dalam menguasai aksen bahasa Jepang. Selain itu, faktor lain yang menjadi penyebab rendahnya kemampuan pembelajar dalam mengidentifikasi aksen bahasa Jepang berdasarkan hasil observasi di lembaga tempat subjek belajar, adalah tidak adanya mata kuliah khusus fonetik, meskipun terdapat mata kuliah pendengaran (choukai). Dalam pembelajaran choukai terdapat stimulus- 
stimulus berupa audio, namun tidak dijelaskan bentuk-bentuk stimulus tersebut, sehingga menyebabkan pembelajar kesulitan dalam mengidentifikasi bunyi-bunyi stimulus tersebut. Persepsi bukanlah penerimaan isyarat secara pasif, tetapi dibentuk oleh pembelajaran, ingatan, harapan, dan perhatian. Diperlukan penguatanpenguatan terhadap input untuk membantu pemerolehan aksen yang cukup sulit bagi pembelajar Indonesia.

\section{Pemerolehan Aksen}

Pemerolehan aksen memang merupakan suatu kesulitan bukan hanya bagi pembelajar Indonesia saja. Penelitian yang dilakukan oleh Matsuzaki (1999) terhadap pembelajar Korea mendapati bahwa mereka mengalami kesulitan mengidentifikasi aksen bahasa Jepang, pembelajar masih menerapkan prosodi bahasa ibu. Hal ini diperkuat oleh penelitian Sukegawa dan Sato (1994) dalam eksperimen persepsi aksen dijelaskan bahwa hal itu tidak ada hubungan dengan latar belakang pembelajar yang berlatar belakang aksen maupun yang tidak. Bahkan meskipun pembelajar telah tinggal lama di Jepang sekalipun belum menjamin pemerolehan aksen yang tepat (Nagatomo, 1993). Bagi pembelajar penutur bahasa Inggris dan pembelajar berbahasa China menurut Kawano (1999) pembelajar cenderung dapat menguasai aksen atamadakagata dan nakadakagata lebih awal.

Jika dikaitkan dengan teori pemerolehan bahasa kedua, bahwa tahap awal pemerolehan bahasa kedua yang disebut praproduksi, yaitu periode senyap, pembelajar tak banyak bicara karena mereka hanya memiliki kosakata reseptif hingga 500 kata (Haynes, 2007). Periode ini dapat dikatakan sebagai periode input. Subjek dalam penelitian ini adalah pembelajar bahasa Jepang pemula yang belum mendapat input yang cukup banyak sehingga mereka belum mampu mengidentifikasi kosakata meskipun yang sudah mereka pelajari sebelumnya.

Persepsi bahasa memang merupakan bagian yang cukup sulit dalam pemerolehan bahasa. Bahkan penutur asli sekalipun tidak sepenuhnya dapat menangkap dengan sempurna bunyi-bunyi bahasanya. Byun (2018) telah membuktikan hal itu dalam penelitiannya terhadap penutur asli bahasa Jepang dalam mengidentifikasi aksen bahasa Jepang standar (Tokyo style) menyimpulkan bahwa penutur asli asal Tokyo pun tidak dapat mengidentifikasi dengan tepat pola aksen standar Tokyo. Hal ini memberikan indikasi bahwa penguasaan aksen cukup sulit dan memerlukan cara yang lebih jitu bagi pembelajar asing untuk dapat menguasai aksen. Untuk itu Toda (1998) menyarankan agar pembelajaran lafal diberikan lebih awal pada saat pembelajar mulai mengenal bahasa Jepang.

\section{KESIMPULAN}

Berdasarkan hasil pengolahan data dan pembahasan di atas, maka dapat ditarik kesimpulan bahwa pada kondisi awal belajar bahasa Jepang, kemampuan pembelajar mengenali pola aksen bahasa Jepang secara persepsi masih sangat rendah. Kendati pembelajar telah mempelajari bahasa Jepang sebelumnya, mereka belum dapat mengidentifikasi pola-pola aksen bahasa Jepang. Ternyata aksen bahas Jepang masih merupakan unsur bahasa Jepang yang cukup sulit pemerolehannya. Salah satu penyebab adalah adanya perbedaan sistem bunyi antara bahasa ibu pembelajar dan bahasa target, dan kurangnya latihan khusus mengenai lafal.

Berdasarkan hasil penelitian ini maka dapat direkomendasikan untuk melaksanakan penelitian lanjutan mengenai penerapan latihan pendengaran dengan memilih metode-metode yang sesuai.

Catatan:

Penelitian ini dilaksanakan atas bantuan dana PNBP Universitas Negeri Manado (Unima) tahun 2020. Untuk itu disampaikan terima kasih kepada Rektor dan Ketua LPPM Unima yang telah memungkinkan penelitian ini terlaksana.

\section{DAFTAR PUSTAKA}

3A Network. (1999). Minna no Nihongo. Tokyo: Network 3A Corporation.

Ayusawa, T. (1997). Tokyogo Akusento Kikitori Ni Tsuite, 21seki No Nihongo Onsei Kyouiku Ni Mukete, Monbusho Kakenhi (Souteki Kiso Kenkyuuhi) :Kokusai Shakai ni okeru Nihongo ni tsuite no Sougoteki Kenkyuu. Tokyo: Kenkyuu Seika Houkokusho.

Ayusawa, T. (2000). Akusento SHuutoku no Juudan Kenkyuu: 3nenhan no CHousa Kekka. Nihon Onsei Gakkai.

Ayusawa, T. (2003). Acquisition of Japanese Accent and Intonation by Foreign Learners. Journal of the Phonetic Society of Japan, 7 (2), 47-58.

Brown, D. H. (1980). Principles of Language Learning and Teaching. New Jersey: Prentice Hall Inc. 
Chaplin, J. (2005). Kamus Lengkap Psikologi. Jakarta: Rajawali Press.

Dardjowidjojo, S. (2005). Psikolinguistik: Pengantar Pemahaman Bahasa Manusia. Jakarta: Yayasan Obor Indonesia.

Ellis, R. (1985). Understanding Second Language Acquisition. Oxford UK: Oxford University Press.

Ellis, R. (1994). The Study of Second Language

Acquisition. Oxford: Oxford University Press.

Halim, A. (1984). Intonasi dalam hubungannya dengan sintaksis bahasa Indonesia. Jakarta: Djambatan.

Hatasa, Y., Takahasi, E., \& Ito, K. (2016). Acquisition and assessment of L2 pronunciation skills in Japanese learners. Hiroshima Daigaku Daigakuin Kyouikugaku Kenkyuuka Kiyou, 65, 177-186.

Haynes, J. (2007). Getting Started with English Language Learners: How Educators Can Meet the Challenge. Alexandria, Virginia USA: Assosiation for Supervision and Curriculum Development.

Indah, R. N. (2017). Gangguan berbahasa: Kajian pengantar. Malang: UIN-Maliki Press.

Kawano, T. (1999). Doushi no akusento no shuutoku. Dai2gengo toshite no Nihongo Shuutoku ni kansuru Sougou Kenkyuu, heisei 8-10 nendo kagakuhi hojokin kenkyuu seika houkokusho.

Koizumi, T. (1993). Nohongo kyoushi no tame no gengogaku nyuumon. Tokyo: Taishuukan SHoten, Co.Ltd.

Kuntarto, E. (2017). Memahami Konspsi Psikolinguistik. Jambi: Fakultas Keguruan dan Ilmu Pendidikan Universitas Jambi.

Lado, R. (1957). Linguistic across Cultures: Applied Linguistics and Language Teachers. Ann Arbor: University of Michigan Press.

Maekawa, K., \& Sukegawa, Y. (1995). Kankokujin nihongo gakushuusha ni yoru nihongo chouboin no chikaku. Nihon Onsei Gakkai Zenkoku Taikai, 40-45.

Matsuzaki, H. (1999). Phonetic Education of Japanes for Korean Speakers. Journal of the Phonetic Society of Japan,.3, 26-35.

Minagawa, Y. (1997). Chouon, tan'on no shikibetsuni okeru akusentogata to onsetsu ichi no youin : Kankoku, Thai, Chuugoku, eigo, doitsugo bogowasha no baai. Heisei 9nendo Nihongo Kyouiku Gakkai Shunki Taikai, 123-128.

Minagawa, Y., Maekawa, K., \& Kiritani, S. (2002). Effects of pitch accent and syllable position in identifying Japanese long and short vowels: comparison of English and Korean speakers. Journal of the Phonetic Society of Japan, 6 (2), 88-97.
Minematsu Laboratory, Tokyo University. (2021). OJAD : Online Japanese Accent Dictionary. (Tokyo University) Dipetik 4 1, 2021, dari OJAD: http://www.gavo.t.utokyo.ac.jp/ojad/eng/pages/home

Nagatomo, K. (1993). Juudanteki Dainigengo Shuutoku Kenkyuu: Shokyuu Nihongo Gakushuusha no Chuukan Gengo. Heisei 5-nen Nihongo Kyouiku Gakkai Shunki Taikai Yokoshuu., 149-150.

Najoan, F. R., Yokoyama, N., Isomura, K., Usami, Y., \& Kubota, Y. (2012). The Acquisition of Japanese vowel length contrast by Indonesian native speakers: Evidence from perception and production. Journal of the Phonetic Society of Japan, 16 (2), 28-39.

Najoan, F. R. (2018). Sistem Bunyi Bahasa Jepang. LPPM Universitas Negeri Manado.

Oguma, R. (2000). Eigo bogowasha ni yoru chouon to tan'on no chikaku. Sekai no Nihongo Kyouiku, $10,43-55$.

Suenobu, M. (2020). Factors that affect Japanese pronunciation by Chinese Learners . Japanese studies in East Asia, 3, 235-243.

Sukegawa, Y. (1993). Indonesiajin nihongo gakushuusha no akusento ni okeru tokushuhaku no eikyou. (O. Mizutani, T. Ayusawa, \& K. Maekawa, Penyunt.) D1 han Kenkyuu Happyou Ronshuu, 167-176.

Sukegawa, Y., \& Sato, S. (1994). Kankokujin Gakushuusha no Nihongo Akusento no Chikaku ni okeru Onsetsu Kouzou no Eikyou. Tohoku Daigaku Ryuugaku Sentaa Kiyou, 2.

Sukegawa, Y., \& Sato, S. (1994). Kankokujin gakushuusha no nihongo akusento chikaku ni okeru onsetsu kouzou no eikyou. Tohoku Daigaku Ryuugaku Sentaa Kiyou.

Sukegawa, Y. (1999). Burajirujin nihongo gakushuusha no 2 morago to 3 morago no pitch no jitsugen. Onsei Kenkyuu, 3 (3) , 13-25.

Su'udi, A. (2011). Pengantar Psikolinguistik bagi Pembelajar Bahasa Perancis. Semarang: Widya Karya.

Takashi, O., \& Cutler, A. (1999). Perception of suprasegmental structure in a non-native dialect. Journal of Phonetics, 229-253. doi:https://doi.org/10.1006/jpho.1999.0095

The Japan Foundation. (2009). Onsei o oshieru : kokusai kouryuu kikin nihongo kyoujuhou siriizu 2. (K. K. Kikin, Penyunt.) Tokyo: Hitsuji Shobo.

Toda, T. (1998). Perceptual categorization of the durational contrasts by Japanese learners. Bunka Gengo Kenkyuu, Gengohen, 33, 65-82. Diakses dari http://hdl.handle.net/2241/13650

Toda, T. (1999). Usage and Acquisition of Accent of English Loanwords by Japanese Learners : an Analysis based on Conversational Data from 
English,Chinese and Korean Speakers [in Japanese]. Studies in language and literature Language, (36), 89-111.

Toda, T. (2003). Acquisition of special morae in Japanese as a second language. Journal of the Phonetic Society of Japan, 7(2), 70-83.
Wang, R., Hayashi, R., Isomura , K., \& Arai, J. (2017). Chuugokugowasha ni yoru Nihongo akusento no shuutoku : Chishiki, sanshutsu, chikaku no kankei kara. (C. n. Kenkyuukaihen, Penyunt.) Chuugokugowasha no tame no Nihongo Kyouiku Kenkyuu, 8, 61-75.

\section{INSTRUMEN PENELITIAN}

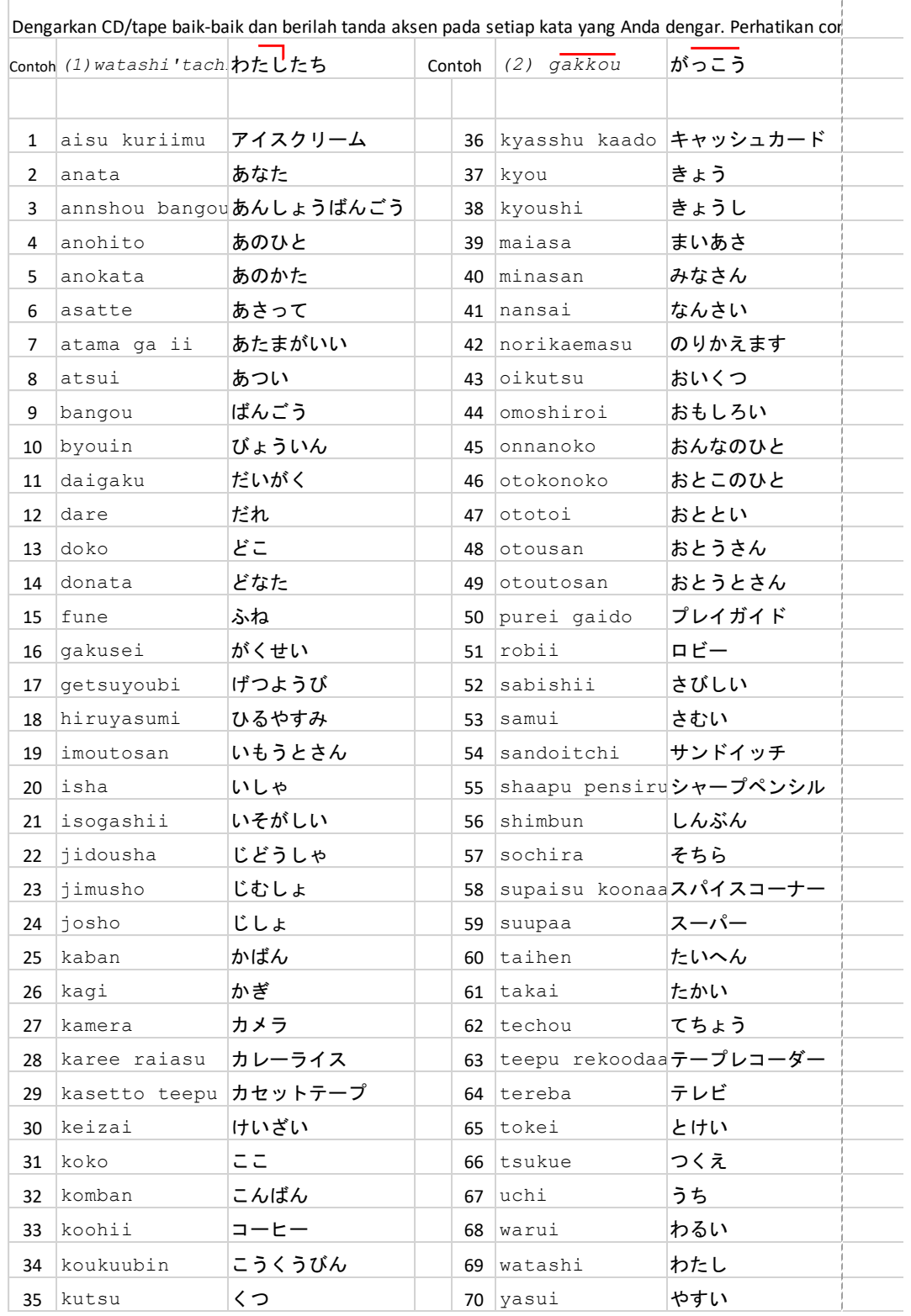

